\title{
BESTEMMING VAN DIE AFRIKAANSE KULTUUR
}

\section{Kultuur}

Kultuur is 'n vierledige geskiedkundige proses wat 'n onskeibare eenheid is van werkers (werker in die wydste sin van die woord), werksaamhede, werke en toe-eienaars, waar die werkers 'n innerlike gemeenskap vorm, 'n gemeenskap wat tegelyk 'n toe-eienaarsgemeenskap is.

'n Kultuur wat in werke (produkte) verstar het en deur geen lewende gemeenskap meer toegeëien word nie, is in werklikheid 'n dooie kultuur. Kultuur leef alleen deur toe-eiening voort.

'n Kultuur kom slegs tot stand op grond van die werksaamhede van werkers op alle terreine van die lewe. Die term en begrip „kultuur” spruit ook regstreeks voort uit die mens se primêre werksaamheid, naamlik die verwerking van die aarde met alles wat daarin is, daaruit voortkom en daarop lewe. D.w.s. deur te delf, te spit, te ploeg en te saai; deur te plant, af te pluk, te stroop en te vleg; deur dood te maak, af te slag, te brei en aanmekaar te las; deur op te stapel, te smee, te bou en te dek, ens., ens.

Werke wat uit hierdie primêre werksaamhede van die werkersgemeenskap voortkom is landerye, boorde, miedens, veestapels, marke, myne, tuie, gereedskap, vervoermiddels, klere, woonplekke, ens., ens.

Die werk, die werksaamheid, die werker, en die toe-eienaar, is verder 'n onafskeibare eenheid wat nooit 'n finale, afgerolde geheel vorm nie. Dit is nie 'n statiese nie, maar 'n dinamiese historiese menslike eenheid.

Die werk en die werksaamheid hang ook ten nouste saam met besondere begaafdhede en talente van die werker, naamlik die begaafdhede om na te boots, toe te pas, te vertolk en te skep in 'n groot verskeidenheid van onderlinge samehange.

Die werker is egter nie 'n enkeling wat saam met ander enkelinge ' $n$ som van losstaande saamgeskakelde enkelinge vorm nie, maar is steeds ' $n$ lewende lid van ' $n$ innerlike geestelike werkersgemeenskap met dieselfde moedertaal, waarin 'n eie geestesgesteldheid, wêreldbeeld, lewenshouding en lewenstyl opgesluit is en tot uitdrukking kom.

Die werke en produkte van die werkersgemeenskap as 
taal- en geestesgemeenskap wat uit 'n gemeenskaplike lewensen wêreldbeskouing put en werk, vertoon as sodanig 'n eie wetmatigheid waarkragtens dit 'n eie bestaan los van die werker en die werkersgemeenskap kan voer. Dit is alleen lewende kultuurwerke solank dit deur die eie en ander kultuurgemeenskappe as eie besit toegeëien word.

Die werke van 'n besondere werkersgemeenskap word deur die eie gemeenskap op aktiewe wyse in en deur die moedertaal as eie besit toegeëien. Hierdie toe-eieningsproses is die wese en kern van alle gemeenskapsvorming, dus van die opvoedingsproses as sodanig. Deur die eie werke vir homself toe te eien, vorm die werkersgemeenskap homself tot volwassenheid en rypheid. In hierdie geval is die werkende gemeenskap tegelyk die toe-eienende gemeenskap, is die produsente-gemeenskap in die wydste sin van die woord tegelyk die verbruikersgemeenskap, ook in die wydste sin van die woord: is die produsentegemeenskap dieselfde as die verbruikersgemeenskap.

Kultuur is dus allereers ' $n$ besondere werkersgemeenskap wat op alle lewensterreine en op grond van besondere talente en begaafdhede werksaam is, waardeur dan ' $n$ groot verskeidenheid van werke wat 'n innerlike eenheid vorm, tot stand kom en deur daardie gemeenskap as sy eie verwerf, toegeëien en gewaardeer word - dit alles as 'n onlosmaaklike, onskeibare eenheid.

In die historiese vormings- en groeiproses van die kultuurgemeenskap kan ons spesifieke fisiese dryfkragte, sosiale beweegkragte en geestelike trekkragte onderskei. Die algemene dryfkragte is selfvoortplanting, selfgelding, selfbeskerming, selfonderwerping, selfbehoud; die vernaamste sosiale beweegkragte is self- en gemeenskapsverwesenliking; terwyl die belangrikste geestelike trekkragte veral die verwesenliking van waardes en ideale, offerdiens e.d.m. is. Hierdie dryf-, beweeg- en trekkraggeheel kom tot openbaring in ' $n$ besondere vaderland en ten opsigte van al die uitdagings waarvoor die gemeenskap te staan kom.

Op elke gegewe tydstip of groeifase behels kultuur as 'n eenheid van werke wat die uitdrukking is van die werksaamheid van ' $n$ besondere werkersgemeenskap op alle lewensterreine en wat die gemeenskap tot sy eie verwerf, die volgende:

(a) bestaansprodukte soos voedselware, klere, wonings, fabrie- 
ke, winkels, banke, ens.;

(b) omgangsvorme soos gedragskonvensies, kuier- en onthaalgewoontes, regspraak, staatsvorme, ens.;

(c) taal-, kuns- en wetenskaplike produkte;

(d) 'n besondere lewens- en wêreldbeskouing en eie godsdiensvorme; en

(e) opvoedkundige ideale en instellings.

In al hierdie kultuurwerksaamhede word gebruik gemaak van besondere tegnieke, wat steeds verander en/of verbeter word. In hierdie opsig vorm die kultuur dan ook tegelyk 'n tegniese geheel sonder om daardeur blote tegniek te word. Alle fases van kulturele groei kan dus tegelyk as tegnologiese ontwikkeling aangedui word. Dit regverdig egter nog nie die omskrywing van 'n kultuurfase of -tydperk as tegnologies net omdat die tegniese aspek daarvan in bepaalde tye sensasionele veranderings ondergaan nie.

Hoewel alle kulture ' $n$ eie en besondere nasionale stempel en karakter dra, is hulle tegelyk ineengeweef met ander kulture waarmee die betrokke kultuurgemeenskap wisselwerkend in kontak is. Hierdie onderlinge wisselwerking is van 'n intiemer aard in geval van verwante kulture. Kultuurverwantskap berus op ooreenstemmende geloofsbeskouings, lewens- en wêreldbeskouings, karaktereienskappe, gemeenskaplike historiese uitdagings, noue geografiese naasbestaan e.d.m. So vind ons in die Westerse wêreld, die Oosterse wêreld, die Arabiese wêreld, en Afrika afsonderlike kulturele verwantskapsgroepe. Binne hierdie en ander kulturele verwantskapseenhede is die onderlinge wisselwerking van intiemer en meer deurslaggewende aard as tussen die verskillende nie-verwante eenhede.

As gevolg van tussenverkeer wat op grond van tegniese ontwikkelings uitgebreider en direkter word, word die wisselwerking tussen nie-verwante kultuurgroepe ook uitgebreider en intiemer, dog bly oorwegend uiterlik van aard. Almal neem op toenemende skaal deel aan ' $n$ eensoortige beskawingsgeheel waarin almal van min of meer dieselfde tegnieke gebruik maak. Langs die weg van die hantering van dieselfde tegnieke begin almal dan meer en meer uiterlike ooreenstemminge vertoon.

Hierdie proses lei daartoe dat ons vandag meer en meer begin praat van wêreldverkeer, wêreldhandel, wêreldkultuur 
en selfs wêreldgodsdiens. Binne hierdie wêreldgehele strewe elke nasionale kultuur-eenheid daarna om hom te handhaaf deur sy eie selfstandigheid verder uit te bou. Dit gaan hier om 'n ,gunstige balans" op alle lewensterreine.

In die geval van die deelnemers aan die wêreldhandel, streef die kultuurvolk daarna om meer goedere en dienste uit te voer as wat hy invoer, om op hierdie wyse 'n gunstige handelsbalans te besit. Net so is dit ook noodsaaklik dat 'n kultuurgemeenskap in sy onderlinge kulturele verhouding met ander gemeenskappe steeds 'n gunstige kultuurbalans moet handhaaf. Dit gaan nie hier oor 'n presiese berekening van kulturele goedere en dienste wat uit- en ingevoer word nie, maar om die innerlike en afsonderlike kultuurinhoud van 'n gemeenskap wat 'n eie bydrae tot genoemde wêreldkultuur kan lewer en wat die positiewe kultuurinhoude, -vorms en -tegnieke van verwante kulture binne die eie lewens- en wêreldbeskouing tot eie onderskeidende besit kan verwerk. Net so min soos 'n gemeenskap kan duld dat sy selfstandige ekonomie deur die wêreldekonomie uitgewis word, kan hy toelaat dat sy kulturele besit deur die wêreldkultuur uitgewis word.

Kultuurgemeenskappe kan hulself dus verryk deur 'n wisselwerking met ander kulture en kan ook op dié wyse hul eie selfstandigheid handhaaf. Op grond hiervan moet ons egter nie aanvaar dat gemeenskappe noodwendig meer van mekaar sal hou as hulle mekaar op hierdie wyse intiemer leer ken nie. Die teenoorgestelde is inteendeel meer waar, naamlik hoe meer gemeenskappe van mekaar weet, hoe minder hou hulle van mekaar, want wat die kommunikasiemedia in ons tyd van mekaar openbaar is meestal van negatiewe aard en minder goed. Die mees algemene opmerking wat 'n mens hoor as jy van land tot land reis, is ,julle moet tog nie glo wat julle van ons in julle land hoor nie". Ons het hier blykbaar te doen met 'n toenemende onderlinge subjektiwiteit hoe meer ons in 'n groter tegniese objektiwiteit opgeneem word.

\section{Bestemming}

Die menslike „stem” as draer van die „woord" van die mens, die woord waarin en waardeur sy angs en sy vrees, sy pyn en vreugde, sy behoeftes en begeertes, sy gevoelens en sy strewe, sy voorstellings, gedagtes en ideale tot uitdrukking kom, is vir 
die mens die mens self; sy stem is hy soos hy hom in sy woord openbaar, onthul en bekend stel.

Bestemming is om as geheelmens van binne, van buite en van Bo gerig te word; van binne op grond van eie begaafdhede en die eie gewete; van buite op grond van bepaalde huislike en ander omstandighede; en van Bo deur God self. In die hoogste en gelukkigste geval word die mens bestem deur sy talente, sy lewensomstandighede en sy diens wat op mekaar ingestem is, d.w.s. met mekaar harmonieer. In en deur hierdie bestemming kom die eie "stem" tot wesentlike en volledige uitdrukking: as menslike "woord": 'n weerspieëling van die „Woord" van God; as mens: die beelddraer van God.

Die bestemming van ' $n$ kultuur is die gerigtheid van die onskeibare eenheid van werkers, werksaamhede, werke en toeeienaars op grond van besondere begaafdhede, besondere omstandighede en 'n besondere Godgewilde roepingsaanvaarding. So word die „kultuurwoord” die uitdrukking van die eie „kultuurstem", in sy hoogste en verhewendste vorm van die Godgewilde Woord as voorskrif en opdrag.

Bestemming as Godgewilde opdrag is in die eerste plek 'n gerigtheid van die individuele gelowige mens, nie as losstaande enkeling nie, maar in sy volle geskapenheid as lid van 'n gesin, 'n familie, 'n taal- en geestesgemeenskap, wat tegelyk 'n geloofsgemeenskap is.

Die Godgewilde bestemming van die mens deurdring allereers sy geloofsbeskouing, wat op sy beurt die wêreld- en lewens. beskouing, die geestesbesit, die geestesvorme, die werksaamhede en werke van 'n besondere gemeenskap van werkers rig en vul.

Hierdie bo-tydelike Godgewilde gerigtheid van die kultuur is 'n gerigtheid waarin die geestelike trekkragte, die sosiale beweegkragte en die fisiese dryfkragte van die menslike gemeenskap opgeneem word en as eenheid tot uitdrukking kom.

Dit bring mee dat die kultuurwerklikheid nie net 'n werklikheid is wat is, wat was en wat word nie, maar tegelykertyd ' $n$ werklikheid is soos dit kan wees en soos dit behoort te wees. In sy „kan-wees-aspek” streef die werklikheid na fisiese perfeksie, na sosiale geluk in die naasteliefde en na geestelike volwassenheid, rypheid en afgerondheid. Dit vorm die wisselwerkende ontvangsbodem vir die „behoort-te-wees"-aspek, d.w.s. die gerigtheid van die kultuur volgens ewige geloofswaarhede 
en geloofswaardes.

Terwyl die bestemming al die funksies van alle kulturele werksaamhede deurdring, doen dit hierdie funksies geen geweld aan nie maar rig dit in die lig van ewige geloofswaarhede. So word die fisiese funksie om te vermenigvuldig, die natuur te onderwerp en daaroor te heers; die sosiale funksie om in liefde saam te bind en die geestelike funksie om te offer en te dien as onskeibare eenheid van Bo gerig op 'n einddoel wat meer en hoër as hierdie funksies is.

Ons moet skerp onderskei tussen funksie, bestemming en toekoms. Binne die geheel van werksaamhede van 'n innerlike gemeenskap van mense onderskei ons drie hooffunksies, naamlik (a) om te dien en te offer; (b) om mense in liefde saam te bind en (c) om orde en geregtigheid in te stel en te handhaaf. Elkeen van hierdie funksies wat in besondere begaafdhede wortel en deur besondere samehange van dryf-, beweegen trekkragte voortgestu word, kom tot eie en selfstandige uitdrukking hoewel hulle binne die geheel van menslike werksaamhede nou en intiem met mekaar ineengeweef is.

Die bestemming van die mens-in-gemeenskap ten opsigte van al hierdie selfstandige funksies kom daarop neer dat hulle deur 'n gerigtheid van Bo as 'n onderskeibare maar onskeibare funksionele geheel in 'n hoër baan gevoer word, dat hulle gerig word op en deur' $n$ geheel van ewige geloofswaardes en -waarhede ter verwesenliking van ' $n$ botydelike roeping. Sy bestemming tref die mens-in-gemeenskap in die uitvoering van al sy funksies, en wel as onlosmaaklike eenheid, nie om dit beter te behartig nie, maar om dit op 'n hoër vlak van menswees in diens te stel van sy geloofslewe.

In sy bestemmingsbesef is nie die menslike „stem", die menslike "woord" ter sake nie, maar die Woord van God. In sy bestemming spreek nie die mens in sy funksionele bestaan nie, maar word hy aangespreek, ,skryf" hy nie, maar verneem hy wat vir hom ",geskryf" staan. Kultuurbestemming is die botydelike aangespreektheid van die mens-in-gemeenskap, van die histories-geworde, histories-groeiende taal- en geestesgemeenskap van werkers in al hul funksioneel-bepaalde werksaamhede waardeur 'n eenheidsgeheel van werke tot stand kom wat in die eerste plek geestesvormend deur dieselfde gemeenskap as eie besit toegeëien word.

Die wesentlike bestemming van 'n kultuur in sy gestelde 
vierledigheid is dus die eenheidsgerigtheid daarvan op innerlike geestesgroei van die mens-in-gemeenskap tot sy verryking en veredeling in diens van God.

In die kultuurbestemming is steeds die kieme van die kultuurverval en kultuurondergang inbegrepe. Die kultuurverval tree in wanneer 'n skeiding tussen die werkersgemeenskap, sy werksaamhede op alle terreine, sy werke en die toe-eiening daarvan van mekaar intree. Dit kan gebeur deurdat die werkersgemeenskap uiteen val in 'n som van gelykgeskakelde enkelinge; of wanneer die werksaamhede van die werkersgemeenskap op alle lewensterreine tot bloot tegniese werksaamhede gemeganiseer word; of wanneer die werke van die gemeenskap 'n eie bestaan voer en nie meer deur die gemeenskap as toe-eienaars tot eie geestesbesit verwerk kan word nie. Dit alles kom in groter mate tot stand wanneer kultuur nie meer in geloofsgronde wortel nie maar slegs uit homself vir homself probeer leef.

Met die verwêreldlikende ontkerstening van die ChristelikWesterse gemeenskap van volkere deur die na-Renaissanscese humanisme, deur die Franse Rewolusie, en in ons tyd, deur die internasionale liberalisme wat die Rewolusie op die Dienste; die tersiêre, terrein kenmerk, word die kultuur van sy bestemming beroof en word dit as funksionele geheel versplinter tot 'n som van losstaande en teenoor mekaar staande werksaamhede en funksieverrigtings.

In hierdie proses word kultuurwerke as oorwegend tegniese werke wat in alle tale „vertaal" kan word, losgemaak van die taal- en geestesgemeenskap waaruit hulle voortgekom het, en as internasionale besit verhandel; word tegniese kultuurprodukte leë doppe wat deur die toe-eienaars met sin en betekenis gevul moet word omdat die makers daarvan self niks of min te sê het wat waardevol en betekenisvol is nie.

Die toekoms van 'n kultuur lê nie alleen in die wyse waarop sy inherente funksies tot vervulling kom nie, maar veral daarin hoe hierdie funksies as geheel deur 'n gerigtheid Bo en van buite homself op ' $n$ hoër vlak in die verwesenliking van ' $n$ eie en afsonderlike roeping tot uitdrukking kom.

\section{Die Afrikaanse kultuur}

Die Afrikaanse kultuurgemeenskap is 'n lewende onderdeel 
van die Christelik-Westerse kultuurgemeenskap. Met laasgenoemde bedoel ons daardie gemeenskap van volkere wat van die Grieke en Romeine deur die Middeleeue heen tot vandag 'n eenheid-in-verskeidenheid vorm van lewens- en wêreldbeskouing; wat 'n gemeenskaplikheid besit ten spyte van belangrike wesentlike onderlinge verskille en van selfs langdurige botsings en oorloë; 'n eenheid wat as Wes-Europa bekend staan, maar wat eintlik 'n skiereiland van Asië is, 'n eenheid van ontwikkeling op alle lewensterreine.

Die Afrikaanse vorm van die Westerse kultuurgemeenskap het nie in isolasie, soos dikwels beweer word, van die Westerse wêreld ontstaan en gegroei nie, maar het van die begin af as erfgenaam van die voor-sewentiende eeuse Westerse wêreld tot vandag in ' $n$ intieme verband met die ontwikkelings van die Westerse wêreld tot 'n eie vorm daarvan uitgegroei.

Die Westerse kultuurgemeenskap het in Suid-Afrika as 'n Afrikaanse kultuurgemeenskap tegelyk 'n inheemse en vaste Afrikavorm aangeneem: die enigste selfstandige ChristelikWesterse kultuurgemeenskap wat met 'n eie taal en kultuur in Afrika ontstaan het.

Die kenmerkende van die Afrikaanse kultuurgemeenskap teenoor die van ander Westerse kultuurgemeenskappe spruit veral daaruit voort dat die Afrikaanse kultuurgemeenskap direk in die Hervorming wortel en wel die Calvinistiese vorm daarvan. Die beginsels van die Hervorming in sy Calvinistiese omlyning het regstreeks die Afrikaanse kultuurgemeenskap se karakter, sy ontplooiing en geestesinhoude gerig, en wel in so 'n mate dat dit vandag nog van deurslaggewende betekenis is.

Die Calvinistiese inwerking op die Afrikaanse lewe en vorming behels die onderwerping van die hele volkslewe op alle lewensgebiede aan die soewereiniteit van God Drie-enig van die Bybel, sodat geen aardse gesag, mag of mens of gemeenskap of beginsel vergoddelik mag word nie, omdat die mens-in-gemeenskap in alles wat hy dink, doen en voel rekening moet hou met die voorskrifte van die Woord van God as absolute norm op alle terreine van die lewe.

Die Afrikaanse volkskarakter vertoon 'n besliste Nederlandse stempel, wat veral tot uitdrukking kom in 'n kragtige handhawing van die eie identiteit; die eienskap om aan te durf en weerstand te bied en verder in die eienskappe van individuele optrede en vindingrykheid, selfs van hardkoppigheid, 
eerder as om kompromieë aan te gaan. Dit gaan hier om 'n individualisme wat in sy gesonde uitinge nie maklik geregimenteer kan word nie.

Die Afrikaner se wese word gekenmerk deur 'n terughoudendheid, deur 'n nie-openheid wat egter kan ontaard tot slimmigheid, omweguitings, wantrouigheid en skuheid wanneer hy meen dat onreg aan hom gepleeg word. Sy karakter verloop in 'n gelykmatige dog heftige tempo. Dit vertoon 'n sware beweeglikheid wat egter nie maklik tot stilstand kom nie. As die beslissende beginselkrag in sy lewe verswak, kry ons weer maklik te doen met ' $n$ lustelose en humeurige traagheid en selfs doellose rondvallery. $\mathrm{Hy}$ is 'n selfstandige tipe wat egter op moedverloor se vlaktes gou terugval op afhanklikhede van allerlei aard.

Die Afrikaner volg en steun die beproefde beginselleier deur dik en dun, en voer graag opdragte in ooreenstemming met daardie beginsels uit. Hy vestig sy vertroue egter nie op die prinse nie maar op die vaste beginselkoers. Hy beplan by voorkeur ver vooruit; omskryf die pad vorentoe tot in die kleinste besonderhede; stel liefs grondwette en konstitusies op en hou hom stiptelik daaraan al verander die omstandighede later. $\mathrm{Hy}$ is 'n planmaker by uitstek, 'n plan waarvan hy maklik die slaaf word.

As tipies Afrikaanse gedragspatrone wat nie 'n inherente deel van sy karakter vorm nie, is in die verlede dikwels slimmigheid, afguns en twissoekery genoem. Hy sou dan wantrouig teenoor vreemdelinge staan, 'n slag probeer slaan deur ,slim" te wees en die ander man uit te oorlê. Hierdie gedragspatroon kom egter slegs tot uitdrukking in omstandighede waarin die Afrikaner onseker voel, hom bedreig voel, of meen dat hy te kort gedoen word en waaraan hy nie deur direkte optrede 'n einde kan maak nie. As hierdie omstandighede verdwyn, verdwyn hierdie gedragspatrone ook.

Die Afrikaanse volkswese is egter van sy wordings- en groeijare af diep gewortel in die Calvinisme wat dit nie alleen kleur en stempel nie, maar dit ook rig en verdiep. Eintlik is hierdie volkskarakter in 'n groot mate tegelyk die produk van sy Calvinistiese geloofsbeskouing. Dit gaan hier om 'n wisselwerking waar inhoud en vorm nie steeds duidelik onderskei kan word nie.

Die Christen-Afrikaner omskryf sy lewens- en wêreld- 
beskouing by voorkeur as Christelik-nasionalisme. Dit behels dat die Afrikaner in al sy werksaamhede op alle lewensterreine in die lig van die Bybelse waarhede en voorskrifte worstel met 'n werklikheid wat nie altyd dieselfde bly nie. Dit gaan om onveranderlike beginsels wat in steeds veranderende situasies geïmplimenteer moet word, in die eie sowel as in die lewe van die eie volk. Die implementering daarvan sal ook nooit deur alle Christen-Afrikaners op presies dieselfde wyse omskryf word nie. Ons sal steeds te doen kry met verskillende aksentverskuiwings, wat egter almal lig sal werp op verskillende aspekte van die uitlewing daarvan.

Die mees onderskeidende kenmerk van die Afrikaanse nasionaisme lê egter opgesluit in die eie Afrikaanse taal, wat op Nederlandse grondslag as 'n nuwe selfstandige gemeenskapstaal in Suid-Afrika ontstaan en gegroei het. Die kragtige en onverbreekbaarste saambinding van 'n kultuurgemeenskap vind immers in en deur 'n eie afsonderlike taal plaas. 'n Kultuurtaal is in wese die gemeenskaplike kennisvorm waarin die gemeenskap sy gehele werklikheid herskeppend beheers. Dit is die diepste bron van gemeenskaplike handeling en skepping op alle lewensterreine. 'n Eie kultuurtaal is die belangrikste voorwaarde vir die ontstaan en voortbestaan van 'n volk as 'n afsonderlike volk. Handhawing van jou eie taal is tegelyk handhawing van jou eie volksgemeenskap.

Soos in die geval van alle Westerse kultuurgemeenskappe, is verteenwoordigende en beslissende leierskap ' $n$ onontbeerlike voorwaarde vir die selfstandige voortbestaan van 'n eie kultuurgemeenskap. 'n Volk kan voortbestaan en selfstandig word desnoods sonder 'n omgrensde vaderland, soos in die geval van die Jode voor die totstandkoming van die Staat Israel, maar sonder begaafde leiers steek hy vas in sy groeiproses. Die Afrikaanse gemeenskapsgroei se besondere karakter dank hy ook aan die wyse waarop dit beliggaam en vertolk is deur groot volksleiers soos Piet Retief, Paul Kruger, pres. M. T. Steyn en andere.

'n Besondere onderskeidende eienskap van die Afrikaanse kultuurgemeenskap is die wyse waarop dit van die begin sy verantwoordelikheid teenoor en sy verhouding tot veral die Bantoevolke van Suid-Afrika verstaan en uitgebou het. Hierdie verhouding is diep gewortel in sy Calvinistiese oortuiging dat hy vir sy medemens verantwoordelikheid tot eer van sy Skepper 
moet aanvaar, dat hy nie oor sy medemens mag heers en hom tot 'n slaaf vir sy eie oogmerke mag verneder nie. Dit het uitgeloop op die tipiese Afrikaanse tradisionele opvatting van 'n voogdyskap-verantwoordelikheid teenoor mense wat nog nie op hul eie bene kan staan nie en nog nie vir hulleself kan sorg nie. Dat dit konsekwent moes uitloop op die beginsel van afsonderlike gemeenskapsontwikkeling deur selfontwikkeling, en nie op integrasie van die Afrikaanse met ander inheemse volkere nie, is eintlik vanselfsprekend. Die sogenaamde apartheidsbeleid, veral in sy huidige vorm van volkere-medeverantwoordelikheid vir almal se toekoms as afsonderlike en selfstandige volkere, is ' $n$ tipiese onderskeidende geestesinhoud van die Afrikaanse kultuurgemeenskap.

'n Tweede belangrike en onderskeidende faktor ten opsigte van die Afrikaanse kultuurlewe is die noue ineengevlegtheid daarvan met die Engelse kultuurlewe. Die Afrikaanse en Engelse kultuurgemeenskappe in Suid-Afrika is in hul saam woon, saam werk, saam voel en saam dink binne dieselfde staat, ten spyte van onderlinge oorloë in die verlede en voortgesette politieke stryd tot in die jongste tyd, geleidelik vasgevang in 'n proses van wedersydse aanpassing wat nie op assimilasie van die een deur die ander uitgeloop het nie, maar wel tekens toon van toenemende politieke samewerking en van kulturele integrasie. Die positiewe bydrae van elkeen van hierdie twee kultuurgemeenskappe in die proses van toenemende kulturele integrasie is verskillend ten opsigte van die onderskeie kultuurterreine:

(a) Die Afrikaans/Engelse kulturele integrasie het op die lewensbeskouingsvlak die minste vordering gemaak, aangesien op hierdie gebied die Afrikaanse en Engelse opvattings lynreg teenoor mekaar staan. Terwyl die Afrikaanse beskouings direk wortel in die Calvinisme, wortel die van die Engelse gemeenskap hoofsaaklik in die Humanisme, wat meer verband hou met die deistiese geloofsbeskouing. Hieruit vloei onder meer voort dat die Afrikaanse kultuurgemeenskap in alle omstandighede 'n beginselgrondslag vir sy dink en doen soek, terwyl in die geval van die Engelse kultuurgemeenskap die nadruk meer val op die pragmatiese, d.w.s. op 'n praktiese benadering wat tot die gewenste resultaat moet lei.

(b) In die staatkundige lewe is die Engelse bydrae tot 'n geïntegreerde kultuurlewe veral opgesluit in die Engelse 
parlementêre stelsel en die Engelse vorm van demokratiese bestuur, wat die nadruk meer op die staatshurgerskap as 'n totaliteit van al die onderdane van die Staat laat val: alle staatsburgers is hiervolgens, afgesien van kulturele en ander verskille, as lede van dieselfde staat, lede van dieselfde „nasie”. Hierteenoor spruit die spesifieke Afrikaanse bydrae tot ons gemeenskaplike staatslewe voort uit die Calvinistiese Republikeinse tradisie as staatkundige vormaanneming van die eie kultuurlewe, hoewel dit nog nie 'n finale afronding gevind het nie. Hierby kom die tipiese Afrikaanse invoeging van die nieblanke gemeenskappe in ons staatslewe as afsonderlike gemeenskappe en nie as individuele burgers daarvan nie.

(c) In die regspleging het die Afrikaanse Romeins-Hollandse regstradisie homself grootliks gehandhaaf met bymenging van die elemente van die Engelse Gemene Reg, die Engelse Bewysleer en Engelse regsvorming deur presedente.

(d) Die Afrikaans/Engelse integrasie op maatskaplike gebied, d.w.s. wat gedragsmaniere, omgangsvorme en lewenstyl betref, dra die oorwegende en byna uitsluitende stempel van die Engelse kultuurgemeenskap. Ons eetgewoontes, die manier waarop ons aantrek, ons untspanningsvorms, die manier waarop ons onthaal, ons sosiale etikette, ens. is reeds uitsluitend geskoei op tipies Engelse vorme.

(e) Op ekonomiese terrein het die Afrikaans/Engelse integrasie gelei tot oorwegende Engelse industriële, kommersiële en finansiële vorme, terwyl die Afrikaanse bydrae hoofsaaklik tot nog toe tot die landbougebied beperk gebly het. Ons ekonomiese lewe, uitgesonderd die landbou, dra dus ook oorwegend 'n Engelse stempel.

(f) Op onderwysgebied het die integrasie van Afrikaanse en Engelse bydrae sover gevorder dat dit eintlik moeilik is om vandag te onderskei watter bestanddele van Afrikaanse en watter van Engelse herkoms is. Die Afrikaanse stempel op onderwysgebied is egter nog geleë in die feit dat die onderwys nie losgemaak is van die godsdienstige lewe nie. Nietemin het die stelsel van tweetaligheid op onderwysgebied die Afrikaner meer blootgestel aan die inwerking van Engelse kultuurinhoude as wat dit die Engelssprekende aan Afrikaanse kultuurinhoude blootstel, veral wat ons universiteite betref. Dit gaan hier oor die feit dat verreweg die grootste persentasie van teksboeke wat gebruik word Engels is of van Engelse oorsprong is. 
Uit die voorafgaande is dit dus duidelik dat daar reeds in Suid-Afrika op toenemende wyse 'n geïntegreerde Suid-Afrikaanse kultuurgemeenskap as Westerse gemeenskap besig is om tot stand te kom, terwyl dit nie altyd maklik is om die presiese Afrikaanse en presiese Engelse bydrae tot hierdie integrerende gemeenskap met sy twee tale en nog onderskeibare kultuurinhoude en kultuurvorms te bepaal nie. Die feit dat die twee tale selfstandig langs mekaar bestaan en in elkeen van hierdie tale nog grootliks eie wesentlike kultuurinhoude hulle neerslag vind, dui egter daarop dat die proses van integrasie nog lank nie voltooi is nie.

Daar kan en is dus nog geen sprake van 'n AfrikaansEngelse kultuureenheid in Suid-Afrika nie, maar oorwegend wel nog van 'n kultuur-tweeheid. Politieke samewerking wat toenemend in verskillende tye op verskillende maniere tot uiting kom, beteken ook geen politieke Afrikaans-Engelse eenheid nie, aangesien samewerking van 'n groot aantal kiesers van albei kultuurgroepe in gemeenskaplike belang nog nie eenheid van lewens- en wêreldbeskouing, van geloof, van geestesinstelling, geestesinhoude en lewenstyl inhou nie.

Afrikaanse kulturele geestesvorming, d.w.s. die toe-eiening van die eie Afrikaanse geestesgoedere tot eie besit geskied deur middel van die toenemende beheersing van die eie moedertaal: Afrikaans, die verklankte draer en beliggamer van die Afrikaanse wêreldbeeld; Afrikaans waarin en waardeur die denkontwikkeling van die Afrikaanse kind plaasvind; Afrikaans waarin die Afrikaanse gemoed homself volledig-direk uitstort en in blywende kunswerke uitdruk; Afrikaans waarin die lewenstyl van die Afrikaner omlyn is, 'n lewenstyl wat in alle maatskaplike omgangsvorme verkonkretiseer is. Hierdie geestesvorming is tegelyk die vorming van die Afrikaanse volkspersoonlikheid, wat in ryke verskeidenheid deur elke individuele Afrikaner anders verlewendig word.

Hierdie geestesvorming wortel in en put regstreeks uit die Calvinistiese geloofsbeskouing dat die werklikheid waarin die Afrikaner hom bevind en waarvoor die jeug toegerus moet word 'n Godgeskape werklikheid is waarin en waaroor God Drie-enig van die Bybel regeer, met die mens wat in sonde verval het maar as gelowige in Christus opgerig word, die medewerker van God op aarde is om sy wil te volbring. Nie die mens nie, maar God regeer. God het nie die wêreld, soos die 
deīsme wil, volgens vaste wetmatighede net aan die gang gesit en dit daarna aan die mens oorgelaat om dit na eie goeddunke in eie belang te rig en te beheer nie, dog Hy gryp gedurig in die verloop van die wêreld en van die mens in. So vestig Hy sy koninkryk op aarde.

\section{Die bestemming van die Afrikaanse kultuur}

Die bestemming, die wesentlike gerigtheid, van die Afrikaanse kultuur in en deur die Calvinisties-Afrikaanse geloofsbeskouing, is ' $n$ gerigtheid in die onskeibare vierledigheid daarvan as historieswordende taal- en geestesgemeenskap van Afrikaners in al hul werksaamhede op alle lewensterreine, wat tot uitdrukking kom in 'n eenheid van waardevolle en blywende werke op grond van 'n besondere samehang van begaafdhede wat tegelyk deur die gehele Afrikaanse gemeenskap geestesvormend en geestesverrykend as eie besit toegeëien word.

Hierdie gerigtheid, hierdie bestemming, hierdie aangespreektheid deur God Drie-enig van die Bybel waarop die Christelik-Afrikaanse kultuurgemeenskap gelowig en gehoorsaam op alle lewensterreine antwoord, is 'n antwoord wat in sy volwaardige bewustheid en volledige eenheid die aanvaarding en vervulling van 'n eie Godgewilde, selfstandige en afsonderlike roeping onder die volke van die wêreld in diens van die eie gemeenskap en van die medemens tot verheerliking van God is.

Die bestemming, die gerigtheid, die aangespreektheid van die Afrikaanse kultuur is ' $n$ gerigtheid van Bo en van buite wat nie vreemd is aan hierdie kultuur nie, maar wat die Afrikaanse kultuurlewe van binne af in daardie gerigtheid opneem. Hierdie opneem van die Afrikaanse kultuur in die gerigtheid, die bestemming van Bo en van buite is daarom tegelyk 'n gerigtheid van binne, 'n gerigtheid waardeur al die werksaamhede van die Afrikaanse gemeenskap op alle lewensterreine gevoer word soos God dit wil na 'n ander, 'n hoër, 'n edeler, 'n ruimer vlak van ,behoort-te-wees".

In hierdie gerigtheid van die Afrikaanse ,hart" vind dan tegelyk die funksievervulling op die onderskeibare selfstandige lewensterreine van die Afrikaanse kultuur plaas, maar dan in hul nouste ineengeweefdheid as die funksievervulling van dieselfde Christen-Afrikaner, naamlik die funksie om te dien en te offer; die funksie om in liefde saam te bind; en die funksie 
om orde en geregtigheid in te stel en te handhaaf.

Vir die Christen-Afrikaner is die funksie om te offer en te dien 'n funksie wat hy as lid van 'n gemeenskap van Christengelowiges, as lidmaat van die Christelik-Protestantse Afrikanerkerk vervul; sy kerk wat die Woord van God verkondig en die heilige sakramente bedien - dié kerk wat nie 'n instelling van mense is nie maar Christus se kerk is wat Hy self in stand hou.

Vir die Christen-Afrikaner is die taal- en geestesgemeenskap waarvan hy lid is, 'n stuk van God se skepping en het dit die funksie om al sy taal- en geesgenote in liefde saam te bind tot eer van God.

Vir die Christen-Afrikaner is die staatsowerheid ná die sondeval deur God ingestel en met die mag van die swaard beklee met die funksie om paal en perk aan die voortwoekering van die sonde te stel, maar met hierdie beperking dat die staatsonderdaan God meer gehoorsaam moet wees as die mens.

Die volledige gerigtheid van die Afrikaanse kultuur is ' $n$ Christelik-nasionale gerigtheid wat in die eerste en belangrikste aspek die gerigtheid van Bo na binne is, 'n gerigtheid waardeur die lewe van die Afrikaner in al sy werksaamhede en in die vervulling van al die gebiedsfunksies van die eie gemeenskap na 'n hoër vlak van diens binne die eie gemeenskap gevoer word, die vlak van diens aan God en medemens. Deur hierdie gerigtheid word hy as mens-in-gemeenskap uit sy alledaagse en bloot individuele bestaan teen die steiltes uit na die hoë bergspitse van vrywees gevoer, word hy uit sy bestaan op die plato's van onverskilligheid en belangeloosheid geruk om met die inset van sy hele wese meer as hyself te word: om geskape na die Beeld van God, die Beeld van God in sy ganse lewe te dra en te weerspieël.

Die Afrikaanse kultuurgerigtheid na binne, wat al sy werksaamhede vorm en waarvan sy hele toekoms in die eerste plek afhang, geskied binne die eie historiese wordings- en groeiproses, 'n proses waardeur sy eie totale werklikheid volledig beheers word. Hierdie beheersing van die eie historiese werklikheid is wesentlik ' $n$ beheersing in en deur die moedertaal, wat nie bloot 'n kommunikasiemedium is nie maar 'n eie gemeenskaplike geestesproduk waarin die eie wêreldbeeld, die eie ervaring, doen en leed, die eie geskiedenis en geestesinhoude hul omvattendste en direkste neerslag vind. Die Afrikaner wat sy taal verraai, verraai nie net homself en sy volk nie, 
maar skei hom tegelyk af van die kultuur en Godgewilde bestemming van sy volk.

Die Christelik-nasionale gerigtheid na binne is dus 'n gerigtheid waardeur die Afrikaanse kultuurgemeenskap gevorm word vir eie diens aan God en medemens. Hierdie gerigtheid na binne behels prime̊r die Christelik-nasionale vorming, opvoeding en onderwys van die Afrikaanse kind en jeug, en wel so dat die doopgelofte van die Christengelowige Afrikanerouer gewetenstrou nagekom word in al sy moedertaal-onderwysinrigtings.

Die kultuurbestemming van die Afrikaner as gerigtheid na binne deur die Woord van God kom so tot uitdrukking in die ideaal van 'n Christelik-nasionale Afrikaanse skoolwese waarin die Afrikaanse jeug in en deur moedertaalonderwys ingelei word in die Christelik-Protestantse geloofsbeskouing soos saamgevat in die geloofsbelydenis van die drie Afrikaanse kerke; ingelei word in die Afrikaanse Calvinistiese lewens- en wêreldbeskouing, in die Afrikaanse Republikeinse staatkunde, die Afrikaanse Romeins-Hollandse regspraak, die Afrikaanse ontginning en verwerking van die Suid-Afrikaanse natuurgawes tot 'n blywende volkstuiste, die Afrikaanse wysbegeerte en wetenskap, die Afrikaanse kunss-appinge, die Afrikaanse maniere van omgang en ontspanning, en die Afrikaanse reëling van die verhouding van voogdelike verantwoordelikheid teenoor die aparte nie-blanke volke van ons land; dit alles as saamhangende Christelik-nasionale geheelinhoud van die Afrikaanse geestesvorming wat in die kenmerkende Afrikaanse lewenstyl van gelowige, nederige, moedige, volhardende en selfstandige roepingsbewustheid sy konkrete afronding vind.

Die na binne gerigtheid van die Afrikaanse kultuur is tegelyk die gerigtheid, die bestemming daarvan binne die ChristelikWesterse kultuurgeheel waarvan dit 'n onderdeel vorm. Terwyl die toekoms van die Afrikaner se kultuur as verwesenliking van sy eie Godgewilde bestemming in die eerste plek afhang van die wyse waarop hierdie bestemming na binne vervul word, is die toekoms daarvan tegelyk afhanklik van die wyse waarop die Afrikaanse kultuur sy bestemming binne die grotere Christelik-Westerse kultuurgeheel volbring.

Die Christelik-Westerse kultuurgeheel waarvan die Afrikaanse kultuur 'n inherente deel vorm, is die van Wes-Europa, Noord-Amerika, Australië en Nieu-Seeland. Dit gaan hier om 
veral die handhawing van 'n gunstige kultuurbalans binne hierdie geheel, d.w.s. om nie net daaruit te neem nie, maar ook daaraan iets van die eie te gee wat deur die betrokke kultuurgemeenskappe tot eie besit verwerk word, en dit nie bloot in vertaalde vorm nie, maar in en deur Afrikaans waarin die Afrikaanse kultuurlewe sy direkte en omvattende neerslag vind.

Die Afrikaanse kultuur vertoon al die inhoude, al die kenmerke, al die ontwikkelings en verskynsels van die grotere Westerse kultuurgemeenskap waarvan dit steeds 'n lewende en inherente onderdeel vorm en waarvan dit nooit losgemaak of geïsoleer kan word nie. Die lotgevalle en toekoms van die Westerse kultuurgemeenskap behels ook die lotgevalle en toekoms van die Afrikaanse kultuurgemeenskap. As die Westerse gemeenskap ten gronde gaan, sal ook die Afrikaanse gemeenskap se einde aanbreek. Die Westerse mens van ons tyd, as hy hom in die toekoms sal handhaaf, sal waarskynlik in homself verenig die gebalanseerdheid van die Antieke Mens, die Christelike geloof van die Middeleeuse Mens en die oneindigheidstrewe van die Moderne Mens, maar dan sonder die waan dat hy alles self vermag en dat sy vryheid ongebonde is. In 'n dergelike groeifase sal die Afrikaanse kultuur sy hoogste eie positiewe bydrae tot die Westerse kultuurgeheel lewer.

In hierdie Westerse kultuurbestemming as geheel het ons egter tegelyk te doen met drie geestesstrominge wat ook die Afrikaanse kultuurlewe tref en waardeur dit as geheel ten gronde gerig word, naamlik die humanisme, die kommunisme en die internasionale liberalisme. Hierdie drie geestesstrominge vorm eintlik die drie samehangende fases van die ontkerstening en verwêreldliking van die Westerse kultuur sedert die Middeleeue.

Die gerigtheid van die Afrikaanse kultuurbestemming na binne as inherente deel van die Westerse kultuur word in ons land veral deur die Afrikaans-Engelse kultuurverhouding in al sy inhoude en aspekte getref. Die toenemende Afrikaans-Engelse kultuurintegrasie sal lei tot 'n andersgerigtheid van die Afrikaanse kultuur indien hierdie proses aan homself oorgelaat word. Immers, die gerigtheid van die Engelse kultuur binne Westerse verband en daarom ook in Suid-Afrika, is in wese en kern 'n teenstelling tot die Afrikaanse kultuur en lei so tot tweespalt. Terwyl die Afrikaanse kultuur Calvinisties gerig word, is die Engelse kultuur wesentlik deisties gerig. Dit plaas 
die Afrikaner voor ' $n$ besliste keuse. Hy kan nie altwee gerigthede tegelyk in sy kultuurlewe aanvaar en onderskryf nie. Daarby kom nog dat Afrikaans waarin die Afrikaanse kultuur in sy onskeibare vierledigheid sy neerslag vind, dus as geestesproduk wesensverskillend ten opsigte van Engels as taal en geestesproduk is. Die Afrikaanse en Engelse kulture kan dus nie op gelyke of ander maniere met mekaar vermeng word nie sonder dat die een deur die ander in 'n wyer verband opgeneem word, en die eie kenmerkende inhoude wat wesentlik in stryd met die van die ander is, dan geleidelik op die agtergrond gedryf word en as sodanig eindelik wegval.

Die bestemming van die Afrikaanse kultuur as 'n gerigtheid na binne waardeur die eie gemeenskap gevorm en na 'n hoër vlak gevoer word en waardeur tegelyk 'n eie positiewe bydrae binne die grotere Westerse kultuurgeheel gelewer word, is verder ook ' $\mathrm{n}$ gerigtheid ten opsigte van die verskillende kulture van Afrika waarmee dit 'n nie-verwante geheel vorm. Die gerigtheid van die Afrikaanse kultuur ten opsigte van die Afrika-kulture is daarom nie dieselfde soos in die geval van die Christelik-Westerse kulture, wat 'n gerigtheid na binne is nie, maar is 'n gerigtheid wat die Afrika-kulture betref, kultureel daarteenoor. Die toekoms van die Afrikaanse kultuur is daarom in 'n baie mindere mate afhanklik van sy verhouding tot die Afrika-kulture, ook van die Oosterse kulture, as van die Westerse kultuurgeheel.

Terwyl die Afrikaanse kultuur in Afrika ontstaan en gegroei het, moet die omskrywing „Afrika” nader omlyn word. In Afrika het ons te doen eintlik met vier Afrikas, naamlik Arabies-Noord-Afrika, Neger-Midde-Afrika, Bantoe-Suidelike Afrika en Christelik-Westerse Suider-Afrika. Laasgenoemde bestaan uit Afrikaners, Engelse en Engelstalige Suid-Afrikaners, Portugese, en Westerse Rhodesiërs. Die Bantoe-Suidelike Afrika behels veral die Bantoevolkere in Suid-Afrika en binne die ander gebiede waar die Westerse kulture as afsonderlike gemeenskappe bestaan. Neger-Afrika is geleë tussen hierdie Bantoe-gebiede en die Arabiese Noord-Afrika. Arabiese Noord-Afrika op sy beurt is nou ineengeweef met die Arabiese Nabye Ooste. Verder het ons in Suid-Afrika nog te doen met ' $n$ inheemse Kleurlingbevolking en met ' $n$ Indiërbevolking wat as verlengstuk van die Indies-Pakistaniese kultuurgemeenskap in Suid-Afrika 'n blywende tuiste vind. 
Die gerigtheid van die Afrikaanse kultuur binne Afrikaverband, is primêr 'n gerigtheid om ten opsigte van al hierdie verskillende nie-verwante kultuureenhede die evangelie in te dra, om hulle tot selfopvoeding te stimuleer en te help en om buurtskapdienste, veral van tegniese aard, te lewer. Hierdie kerstenende, opvoedende en en dienslewerende bestemming geskied steeds te midde van die andersoortige realiteite en ontwikkelinge van die verskillende Afrika-volkere-eenhede.

Die geheelbestemming van die Afrikaanse kultuur as gerigtheid deur die Woord van God, word gedra, vertolk en beliggaam deur gelowige Christen-Afrikanerleiers op alle lewensterreine ten opsigte van al die werksaamhede en funksies wat daarin tot uitdrukking kom en wat deur die Afrikaner as eie geestesbesit toegeëien word. Die Calvinistiese bestemming van die Afrikaanse kultuurlewe beteken dus nie dat alle Afrikaners Calviniste is of dat alle kulturele werksaamhede en werke van Afrikaners Calvinistiesgerig is nie. Waarom dit wel gaan is dat belydende Christen-Afrikanerleiers steeds die Afrikaanse kultuurlewe in al sy wesentlike aspekte, inhoude, vorms en uitinge ondubbelsinnig en ongekwalifiseerd bind aan die ewigonveranderlike beginsels, sekerhede, waarhede, waardes, norme en standaarde wat in die Woord van God aan die gelowige geopenbaar word.

Hierby kom dat die Christen-Afrikanerleiers as draers en vertolkers van die Christelik-Protestantse kultuurbestemming van hul volk, soos dit histories vaste vorm aanneem, nie hierdie beginsels, waarhede en waardes wysig om dit by veranderende lewenssituasies aan te pas nie, maar dit in hierdie groeiproses sal implementeer sonder afwatering - 'n afwatering wat tot kultuurverval sal lei.

S.A.U.K., Johannesburg. 